\title{
TOLERANCE IN MULTI-RELIGIOUS SOCIETY FOR NATIONAL SECURITY: THE NIGERIAN EXPERIENCE
}

\author{
Oluwasegun Peter Aluko \\ http://dx.doi.org/10.4314/og.v13i 1.15
}

\begin{abstract}
In Nigeria, there are three main religions recognised by the people; Christianity, Islam and the Indigenous religion. These religions have differences that have brought about unrest as the tolerance level has got to a point of polarity. The various unrests have led to national insecurity of the country. The paper examined the various religious differences that permeate the lives of Nigerians. However, no matter the differences, it does not negate the fact that there are many other apparent similarities that bring these religions together. These similarities, when put into consideration can bring about the much needed tolerance and understanding. It also looked at the ways the religious writings have supported tolerance with other religions for the peace and security of the nation. The paper found out that tolerance among religious faiths is a major factor in achieving national security in the country. It concluded that no religion should see itself as being superior to another; there is only one Goal, but there are various paths to such a goal. The study employed both primary and secondary sources of data. The primary source includes the Bible and the Qur'an while the secondary source includes books, journal articles and the Internet. The data collected were analysed using sociological approach.
\end{abstract}

Keywords: National Security, Multi-Religious, Tolerance, Understanding

\section{Introduction}

Religion, a cardinal organ in the Nigerian society, permeates every aspect of lives of the people. Nigeria being a multi-religious country has suffered many setbacks as a result of religious crisis. Religion that is meant to be a platform for peace, stability, progress, development and unity has apparently been used by many to disrupt the wellbeing of person and society (Adefarasin 293). Peil states that Nigeria was riddled with diverse problems such as bribery, 
corruption, tribalism, nepotism, political acrimony and religious fanaticism. But out of these vices, religious problem speedily became a cankerworm, which, till today, has eaten deep into the fabric of our national solidarity (qtd. in Owoeye194).

Religion that is supposed to supplement the given laws of the country is now being used by the extremists or the fanatics for their selfish purposes. The resultant effect of this is insecurity that the nation finds itself. The major religions in Nigeria are Christianity, Islam and Indigenous Religion amongst others that are not so known and practiced. The aim of this paper is to look at the various religious differences and similarities that ensued among the three main religions in Nigeria; to see some level of how toleration and understanding can go a long way in accomplishing national security. This paper argues that for Nigeria to know peace there will have to be tolerance as regards religion.

\section{Tolerance and Understanding: A General Overview}

There are so many opinions that pervade around people in the world. These opinions may either be true or false. People may like or dislike these opinions depending on what they feel is right/wrong to them. This brings about tolerance which is to make them accommodate others. According to Stephan Kokew, tolerance is an acceptance in the way that it means a willingness to accept behaviour and beliefs which are different from your own, although you might not agree with or approve of them (2). Tolerance comes from the ability to cope with divergent opinions without having to take up grievances, up to the extent of taking up arms. When there are no unstable moments in the country, there would be no need for tolerance. However, the case is not the same here in Nigeria as there are needs for tolerance especially among the adherents of the various religions in the country.

Webster's New Explorer Encyclopedic Dictionaryin trying to define understanding, gives it "as a friendly or harmonious relationship; an agreement of opinion or feeling; adjustment of differences; a mutual agreement not formally entered into but in some degree binding on each side" (2015). In order to bring about national security, there have to be adjustment of differences. The differences in religious beliefs are so numerous; they are just like the various tribes that are in Nigeria. Many of the problems besieging 
Nigeria today come from the fact that her citizens who are believed to be very religious have not been able to understand other religions; or, they understand but really want their own religion to oversee the others religion. These have really led to so many losses of lives and property in Nigeria ever since her independence (Owoeye 194196). Religious fanatics have brought about intolerance in the country which has in turn wrecked much havoc on the peace of the country. The major religions in the country while trying to outpace the other have not really been able to tolerate one another. Oshitelu says "religious intolerance, more often than not result into conflict which has the following: antagonism, antipathy, contention, contradiction, difference, disagreement, discord, dissention, friction... opposition, strife...." (qtd. in Ayantayo 73).

\section{National Security}

There is no clear definition of what the term "national security" means. There is no single universally accepted definition of national security. It means many things to many people. However, in order to look for a given definition, one can say that national security is the requirement to maintain the survival of the state through the use of economic power, diplomacy, power projection and political power (Wikipedia). It is also the protection or the safety of a country's secrets and its citizens (Macmillan Online Dictionary). Nevertheless, according to PranbhakaranPaleri, the author of National Security, Imperatives and Challenges, national security may be defined as:

The measurable state of the capability of a nation to overcome the multi-dimensional threats to the apparent well-being of its people and its survival as a nation-state at any given time, by balancing all instruments of state policy through governance, that can be indexed by computation, empirically or otherwise, and is extendable to global security by variables external to it (521).

This definition by Paleri gives insight into one of the major problems that Nigeria is being plagued with. Many crises have erupted in the name of religion. Most of the crises in Nigeria today are still religious-backed (with political undertone). The Boko- 
Haram trauma in the Northern part of the country (especially in Borno State)is bringing about a cause for many Nigerians not to have national security; it has brought about the citizens in this state having a sleepless night (even Nigeria as a whole). Whatever has not been able to make the citizens of a country to have rest of mind is a call to their security to have been jeopardised.

\section{Religious Differences as a Major Cause of Religious Intolerance}

The indigenous religion is the only religion practiced by Nigerians before the emergence of Islam and the Christian missionaries. Most people readily accepted these two foreign religions. Though, some of the inhabitants of the land were very syncretic in their manner of acceptance, this does not mean they did not accept the religions for their own purposes and advantages. This acceptance brought about the beginning of differences as these foreign religions brought with them their own various beliefs and practices. In agreement with John S. Mbiti who says:

This rapid spreading of the Christian faith where people have been predominantly followers of African religion provokes interesting questions. That which had been seen as the enemy of the gospel turns out (to me) to be indeed a very welcoming friend African religion has equipped people to listen to the gospel, to discover meaningful passages in the Bible, and to avoid unhealthy religious conflict (817-820).

From this statement by Mbiti, one would have expected that there would not be need for any rancour but the reverse is the case in Nigeria. A careful study of the three major religions show that there are remarkable differences which lead to intolerance among practitioners of these religions. The table below shows areas of difference in the three religions. 
Aluko: Tolerance in multi-religious society...

Religious Differences that Exist Among the Major Religious

Faiths in Nigeria

\begin{tabular}{|c|c|c|}
\hline Christianity & Islam & $\begin{array}{l}\text { Indigenous } \\
\text { Religion }\end{array}$ \\
\hline \multicolumn{3}{|c|}{ Date Founded } \\
\hline c. $30 \mathrm{AD}$ & $622 \mathrm{CE}$ & No exact date \\
\hline \multicolumn{3}{|c|}{ Founders and Early Leaders } \\
\hline $\begin{array}{c}\text { Jesus Christ, Peter and } \\
\text { Paul }\end{array}$ & Muhammad & Ancestors \\
\hline \multicolumn{3}{|c|}{ Place Founded } \\
\hline Palestine & Arabian Peninsula & Africa \\
\hline \multicolumn{3}{|c|}{ Official Languages } \\
\hline Aramaic and Greek & Arabic & $\begin{array}{l}\text { Languages of the } \\
\text { tribes that are } \\
\text { practicing it }\end{array}$ \\
\hline \multicolumn{3}{|c|}{ Sacred Text } \\
\hline $\begin{array}{c}\text { Bible }=\text { Old Testament } \\
(\text { Jewish Bible })+\text { New } \\
\text { Testament }\end{array}$ & Qur'an & No sacred text \\
\hline \multicolumn{3}{|c|}{ Inspiration of Sacred Text } \\
\hline $\begin{array}{l}\text { Views vary: literal word } \\
\text { of God, inspired human } \\
\text { accounts, or of human } \\
\text { origin only }\end{array}$ & Literal word of God & Oral transmission \\
\hline \multicolumn{3}{|c|}{ Summaries of Doctrines } \\
\hline $\begin{array}{c}\text { Apostles' Creed, Nicene } \\
\text { Creed }\end{array}$ & Six Articles of Faith & $\begin{array}{l}\text { Ancestral worship, } \\
\text { belief in divinities, } \\
\text { magic and medicine }\end{array}$ \\
\hline \multicolumn{3}{|c|}{ Religious Law } \\
\hline Canon Law (Catholics) & Sharia & Oral Transmission \\
\hline \multicolumn{3}{|c|}{ Other Written Authority } \\
\hline $\begin{array}{l}\text { Church fathers, church } \\
\text { councils, ecumenical } \\
\text { creeds (all branches; } \\
\text { papal decrees, canon law } \\
\text { (Catholics) }\end{array}$ & Hadith & $\begin{array}{l}\text { Ifa literary corpus in } \\
\text { some ethnic groups }\end{array}$ \\
\hline \multicolumn{3}{|c|}{ Other Spiritual Beings } \\
\hline Angels and demons & Angels, demons and jinns & Divinities, ancestors, \\
\hline
\end{tabular}


Ogirisi: a new journal of African studies vol. 132017

\begin{tabular}{|c|c|c|}
\hline & & spirit possession \\
\hline \multicolumn{3}{|c|}{ Identity of Jesus } \\
\hline $\begin{array}{l}\text { Son of God, God } \\
\text { incarnate, saviour of the } \\
\text { world }\end{array}$ & $\begin{array}{c}\text { True prophet of God, } \\
\text { whose message has been } \\
\text { corrupted }\end{array}$ & $\begin{array}{c}\text { The person that } \\
\text { reveals a God they } \\
\text { knew all along. He } \\
\text { is a messenger of the } \\
\text { same God their } \\
\text { forefathers and } \\
\text { mothers agreed it } \\
\text { (Mbiti "The } \\
\text { Dialogue") }\end{array}$ \\
\hline \multicolumn{3}{|c|}{ Mode of Divine Revelation } \\
\hline $\begin{array}{l}\text { Through prophets and } \\
\text { Jesus (as God Himself), } \\
\text { recorded in the Bible }\end{array}$ & $\begin{array}{l}\text { Through Muhammad, } \\
\text { recorded in the Qur'an }\end{array}$ & $\begin{array}{l}\text { Through the priests, } \\
\text { doctors, priestess }\end{array}$ \\
\hline \multicolumn{3}{|c|}{ Human Nature } \\
\hline $\begin{array}{l}\text { "Original sin" inherited } \\
\text { from Adam - tendency } \\
\text { towards evil }\end{array}$ & $\begin{array}{l}\text { Equal ability to do good } \\
\text { or evil }\end{array}$ & $\begin{array}{c}\text { Ability to do good or } \\
\text { evil }\end{array}$ \\
\hline \multicolumn{3}{|c|}{ Means of Salvation } \\
\hline $\begin{array}{l}\text { Correct belief, faith, good } \\
\text { deeds, sacraments (some } \\
\text { Protestants emphasize } \\
\text { faith alone) }\end{array}$ & $\begin{array}{c}\text { Correct belief, good } \\
\text { deeds, Five Pillars }\end{array}$ & $\begin{array}{l}\text { Seek God and, } \\
\text { moved by grace, } \\
\text { strive by their deeds } \\
\text { to do His will as it is } \\
\text { known to them } \\
\text { through the dictates } \\
\text { of conscience. To } \\
\text { reach the spirit-land } \\
\text { of the one's } \\
\text { ancestor, to be } \\
\text { venerated by one's } \\
\text { descendants as an } \\
\text { ancestor, and } \\
\text { eventually (at least } \\
\text { in some traditions) } \\
\text { to be reincarnated } \\
\text { (Adamo“Christianity } \\
\text { and the African }\end{array}$ \\
\hline
\end{tabular}


Aluko: Tolerance in multi-religious society...

\begin{tabular}{|c|c|c|}
\hline & & $\begin{array}{c}\text { Traditional } \\
\text { Religion(s)"). }\end{array}$ \\
\hline \multicolumn{3}{|c|}{ God's role in Salvation } \\
\hline $\begin{array}{l}\text { Predestination, various } \\
\text { forms of grace }\end{array}$ & Predestination & Life after death \\
\hline \multicolumn{3}{|c|}{$\begin{array}{l}\text { View of the other Religions } \\
\end{array}$} \\
\hline $\begin{array}{l}\text { Islam is respected as a } \\
\text { fellow monotheistic } \\
\text { religion, but Muhammad } \\
\text { is not seen as a true } \\
\text { prophet. See ATR as } \\
\text { being idolatry. }\end{array}$ & $\begin{array}{l}\text { Christians are respected as } \\
\text { "People of the Book," but } \\
\text { they have mistaken beliefs } \\
\text { and only partial } \\
\text { revelation. See ATR as } \\
\text { being idolatry. }\end{array}$ & $\begin{array}{l}\text { Respect both Islam } \\
\text { and Christianity }\end{array}$ \\
\hline \multicolumn{3}{|c|}{ House of Worship } \\
\hline $\begin{array}{c}\text { Church, chapel, cathedral, } \\
\text { basilica, meeting hall }\end{array}$ & Mosque & $\begin{array}{l}\text { Altar, shrine, } \\
\text { temple, tomb, tree, } \\
\text { groove, mountain, } \\
\text { cave }\end{array}$ \\
\hline \multicolumn{3}{|c|}{ Day of Worship } \\
\hline Sunday & Friday & Any day \\
\hline \multicolumn{3}{|c|}{ Religious Leaders } \\
\hline $\begin{array}{l}\text { Priest, bishop, } \\
\text { archbishop, patriarch, } \\
\text { pope, pastor, minister, } \\
\text { preacher, deacon }\end{array}$ & Imam, Shayhk & $\begin{array}{l}\text { Priest, priestess, } \\
\text { elder, doctor }\end{array}$ \\
\hline \multicolumn{3}{|c|}{ Major Sacred Rituals } \\
\hline $\begin{array}{l}\text { Baptism, communion } \\
\text { (Eucharist) }\end{array}$ & $\begin{array}{c}\text { Five Pillars: prayer, } \\
\text { pilgrimage, charity, } \\
\text { fasting, confession of faith }\end{array}$ & $\begin{array}{l}\text { Ceremony, ritual, } \\
\text { festival, prayer } \\
\text { initiation } \\
\end{array}$ \\
\hline \multicolumn{3}{|c|}{$\begin{array}{l}\text { Central Religious Holy Day } \\
\end{array}$} \\
\hline Lent, Holy Week, Easter & Eid-al-Fitr, Eid-al-Adha & $\begin{array}{l}\text { Day differs from } \\
\text { ethnic groups }\end{array}$ \\
\hline \multicolumn{3}{|c|}{ Other Holidays } \\
\hline Christmas, saints days & Mawlid, Ashura & $\begin{array}{l}\text { No other holiday as } \\
\text { such* }\end{array}$ \\
\hline \multicolumn{3}{|c|}{ Major Symbols } \\
\hline $\begin{array}{l}\text { Cross, crucifix, dove, } \\
\text { anchor, fish, alpha and } \\
\text { omega, chi rho, halo }\end{array}$ & $\begin{array}{l}\text { Crescent, name of Allah } \\
\text { in Arabic }\end{array}$ & $\begin{array}{l}\text { Things related to the } \\
\text { people indigenously }\end{array}$ \\
\hline
\end{tabular}


Source: Comparison Chart: Christianity and Islam**

As much as these religious differences exist, there is dire need for the existence of toleration. According to William Reese, Jeremy Taylor developed a theory of toleration on the basis of his own experiences in the time of Cromwell. He argued that religious truth is indemonstrable and heresy an error not of the understanding but of the will. Taylor held that diversity of belief is necessary. Toleration is limited, however, by what is in the public interest and the foundations of faith (461). The differences have been overtly stressed to the extent that intolerance is inevitable. Stressing the differences has led to religious crises in the country. Hence, there is a need to look at the area of similarities.

\section{Religious Similarities}

Having made mention of the various religious differences that exist among the three major religions in Nigeria, it is pertinent to also look into some of the beliefs and practices that brings these religious faiths together. For religious faiths to fully tolerate and understand one another, the area of similarities is one important aspect that can foster peaceful co-existence. The following are ways of similarities of the three major religions in Nigeria:

1. The idea of God: The three major religions in Nigeria believe in God. The name given to God is one of the things that make it to be different. While Christianity employs the word 'God', Islam permits the name 'Allah". To the adherents of the Indigenous religion, the God they believe in is the Supreme God who they call various names according to their dialect like Olodumare and Olorun among the Yoruba, Chineke and Chukwu among the Igbo, Ubangiji among the Hausa etc. (Mbiti "African Peoples;" Ekeke and Ekeopara, "God"). He is seen by these religions as the head of all things, the creator and the controller of the universe.

2. Naming Ceremony: This is the act of giving a name to a new born child. The three major religions are well involved in this act of naming their children. This they do on the eighth day after the birth of the child(ren).

3. Marriage: To the three major religions, marriage is very sacrosanct. These religions believe in the institution of man 
and woman being joined together in matrimony. Marriage in these three religions is for procreation and companionship.

4. Prophets/Diviners and prophecy: There are numerous prophets/diviners in the three major religious faiths. The prophets/diviners predict the future. Predictions seem to belong to the very idea of the prophetic office (Lateju 8). Many patronised them in order to know what the future holds for them. They are known as prophets in Christianity and Islam but known as diviners in the Traditional religion.

5. Healing: This is one of the most interesting aspects of life that the major religious faiths in Nigeria are involved in. Many suffer from various forms of diseases like health, finances etc. Most of the through herbs the traditional healers, the Islamic healer and the Aladura prophets in Nigeria today can heal such a patient with relative ease through spiritual healing process (Babalola 4).

6. Existence of evil: The existence of evil is real in all the three major religions. Evil is the force believed to bring about harmful, painful, or unpleasant events. Evil in the Traditional religion includes both physical and moral evil. God is the one who brings forth good, but human being causes evil to themselves and others' (Adamo "Christianity and the African Traditional Religion(s)").

7. Initiation: The three major religions in Nigeria practice initiation of new members. To be a Christian, you have to be baptised; Muslim, you have to perform holy cleansing; and the Traditional religion, you need to be initiated as the ethnicity permit.

8. Respect for parents: This practice is well accorded in the three major religions. Islam has it in the Qur'an as "And your Lord has decreed that you not worship except Him, and to parents, good treatment. Whether one or both of them reach old age (while) with you, say not to them (so much as), "uff," and do not repel them but speak to them a noble word. And lower to them the wing of humility out of mercy and say, 'My Lord, have mercy upon them as they brought me up (when I was) small.'” (Surat Al-'Isrā' 17:23, 24). Christianity has it in the Bible as "Children, obey your parents in all things: for this is well pleasing unto the Lord" 
(Colossians 3:20). In the Traditional religion, Akilidágògòlòtòókíyèyéẹni A kilídágògòlòtòókí baba ẹni.... ÒwónrínOgbè (One should not be too big to greet one's parents properly, One should not be too pompous to greet one's parents properly) (Salami 250-251).

9. Various Teachings: Love of oneself and one's neighbour, speak truth, it is more blessed to give than to receive, honour the elders, golden rule - "no one of you is a believer until he desires for his brother that which he desires for himself," (Sahih Muslim, Book 1, Number 72). "And as ye would that men should do to you, do ye also to them likewise" (Luke 6:31). E mófèéfẹrẹsímobí $E$ móhùwàikàsíbojì $E$ mósekéimùlètoríàtisùnẹni (Do not cause disaffection within humans Do not behave wickedly to the dead Don't be betrayers of trust because of the day of one's death ... ÒdíOtúá(Salami 244). Teaching on Adultery: "And do not approach unlawful sexual intercourse. Indeed, it is ever an immorality and is evil as a way" (Surat An-Nisa 4:19).

Instead of looking at the verse differences that exist in the various religious faiths, it is imperative for all adherents to look at the many similarities of the religions. These similarities teach on morals that are very germane for the progress of the country.

\section{The Need for Religious Tolerance and Understanding for National Security}

Religious tolerance is not religious indifferences. It consists of valuing the right of another person to hold beliefs that you know absolutely, and without a doubt, to be wrong. Religious tolerance means to refrain from discriminating against others who follow a different religious path. But, tolerance is more difficult to maintain when you know that your religion is true and their religion is wrong (Robinson "Religious Tolerance and Cooperation"). This has been the concept of most of the religions in Nigeria. With this mind set, religious intolerance has been in existence. Not everyone would be willing to live as a second-citizen in his/her country; not everyone would also be willing to accept that his/her religion is not the best. Everyone is interested in being the best.

Religious tolerance is allowing followers of other religions to follow their spiritual beliefs without oppression or discrimination. 
Religious tolerance is a fundamental right in a democracy. Most people believe that religious tolerance, using this definition, is a noble goal, and is vitally necessary for world peace (Robinson "Religious Tolerance and Cooperation"). According to Reese, John Locke confined his discussion to religious toleration, opposing persecution and sanctioning religious differences. Toleration is to be extended to all varieties of religious belief and practice. It extends up to but does not include atheism, apparently on the ground that the state itself rests on certain religious sanctions (Reese 461). The former national anthem of Nigeria that was used from 1960 - 1978 has three stanzas that talks about brotherhood (which talks about oneness in all things, religion inclusive). The first stanza of the anthem says:

Nigeria, we hail thee,

Our own dear native land,

Though tribe and tongue may differ,

In brotherhood we stand,

Nigeria's all are proud to serve,

Our sovereign Motherland.

This stanza talks about brotherhood which is believed to be a feeling of fellowship and sympathy for other people. Nigerians really need to tolerate one another as this will promote oneness as brothers and sisters. Nonetheless, the third stanza of the anthem also talks about the need for all the religious faiths to have tolerance. The stanza is as follows:

O God of all creation,

Grant this our one request,

Help us to build a nation

Where no man is oppressed,

And so with peace and plenty

Nigeria may be blessed.

This stanza points towards religion, calling upon God to help build a nation (Nigeria) where no man is oppressed. It shows that when there is tolerance and understanding among religions, and they come together as one in prayers, coupled with good governance, there can 
always be national security. Notwithstanding, the present national anthem is also construed to work in line with national security. The second stanza of the anthem looks at religions working together and tolerating one another. The stanza is as follows:

Oh God of creation,

Direct our noble cause

Guide our leader's right

Help our youth the truth to know

In love and honesty to grow

And living just and true

Great lofty heights attain

To build a nation where peace and justice shall reign

This stanza talks about the calling upon God who is the creator of all creation (which also include Christians, Muslims and Traditionalists) to direct the noble cause of this nation. This shows that religion has a lot of grip to hold on this nation. When there is intolerance among the various religious faiths that exist in Nigeria, there can be no national security, and as such, no great lofty height to attain.

For the country to have peace from religious crises that have been ravaging her, the religious faiths need tolerance and understanding. When there is peace, citizens can go about their lawful businesses without any fear. With businesses booming, the economy of the nation would also develop. Citizens would live in peace and harmony. Various teachings of these religious faiths when centred on love with one another would enable the citizens to always see themselves as one big family.

\section{The Teachings of Religious Tolerance in Christianity, Islam and Traditional Religion}

There are two passages that are often cited to support religious tolerance in Islam. These verses are as follow:

If Allah so willed, He would have made you a single People, but his plan is to test each of you separately, in what He has given to each of you: so strive in all virtues as in you are in a race. The goal 
of all of you is to Allah. It is He that will show you the truth of the matters in which ye dispute (Surah Al-Ma'idah, Ayah 48).

The other one has it that:

O mankind, we have created you male and female, and We have made you into communities and ethnic groups that you may recognise one another. Verily, the most honourable among you, in the sight of Allah is the most righteous among you. Surely, Allah is All-knowing, All-Aware (Surah al-Hujurat 49:13).

These verses point to the facts that there are so many people in the world and there are many differences as regards religion. Also, there should not be dispute with other religions. One of the fundamental requirements of becoming a Muslim is to manifest belief in the scriptures that God has revealed, one of these being the Torah (The Qur'an and Tolerance).

Christianity on its own part, also talks about tolerance with other religions. The verses are as follows:

...they shall beat their swords into plowshares, and their spears into pruning hooks: nation shall not lift up a sword against nation, neither shall they learn war any more. But they shall sit every man under his vine and under his fig tree; and none shall make them afraid: for the mouth of the LORD of hosts hath spoken it. For all people will walk everyone in the name of his god, and we will walk in the name of the LORD our God for ever and ever (Micah 4:35).

Also, Jesus refused to curse non-believers. Instead of cursing, he would leave and move over to another place. A passage in the Bible has it as follows: 
...they did not receive him...And when his disciples James and John saw this, they said, Lord, wilt thou that we command fire to come down from heaven, and consume them, even as Elias did? But he turned, and rebuked them, and said, Ye know not what manner of spirit ye are of. For the Son of man is not come to destroy men's lives, but to save them. And they went to another village (Luke 9:52-56).

Paul, who is one of the main figures in Christianity, also states one fundamental truth about people in other religion. He said this in his writings to the Corinthians. He says:

Whether therefore ye eat, or drink, or whatsoever ye do, do all to the glory of God. Give none offence, neither to the Jews, nor to the Gentiles, nor to the church of God (I Corinthians 10:31-32).

On the part of the traditional religion, there are proverbs that tend to show how people are to live in peace and harmony. The proverbs go thus:

Mọàfóníwàlónjẹprejọe (When you know the behaviour of your friend, then you are real friends)

Ańjùwónkòseéwíléjó, ijàìlarakòtánbòrò ('We are superior to them' cannot be quoted as an argument or complaint in court; a quarrel due to envy is not settled by the passage of time) (Fasiku 58).

\section{How to Achieve Religious Tolerance and Understanding in Nigeria}

National security is not something that can be bargained for. Nigeria needs it in every facet of life. The following are some of the ways we can achieve religious tolerance in Nigeria:

1. The government should not support any religion far and above other religions. 
2. Ban of inciting religious programmes on the television, radio by the government etc.

3. Teaching of all the major religions (Christianity, Islam and Indigenous Religion) in our schools. When these religions are taught, the pupils will know that there are striking similarities among the religions from their basic beliefs and practices, and thus bring about the much needed tolerance in the nation.

4. Avoidance of preaching that can spark up hatred from other religions.

5. Citizens should be vigilant in order to caution anyone that is willing to bring up any act that can lead to intolerance, knowing fully well that religion is being held in high esteem among Nigerians.

6. The concept of love that these religions preach should not be taken with levity. It should be practiced whole-heartedly and with all diligence.

7. Religious adherents should eschew extremism. Extremism has been a big factor in fuelling the embers of religious crisis in Nigeria. The religious leaders can help in this instance by making sure they let their followers know the real truth (of peace) that is enshrined in their religion.

8. Everyone should see the other person as brother/sister, as this would wave off hatred whatsoever, even as this promotes love.

\section{Conclusion}

National security hinges on the survival of the citizens of the country. The ability to continue to have people that can be called citizens is what makes a country to be called her name. If, however, such a country continues to lose her citizens on the basis of religious crises that ensued from intolerance and the non-understanding of religious faiths, how can such a country develop or continue to exist? No religion should see itself as being superior to another. Sri Chinmoy says: "I fully agree that all religions lead to one truth, the Absolute truth. There is One truth. There is only one Goal, but there are various paths. Each religion is right in its own way." More so, William L. Reese while quoting Proudhon says complete toleration is a necessary condition for progress toward the system of voluntary 
Ogirisi: a new journal of African studies vol. 132017 cooperation which is to replace the present coercive state (Reese 461).

*Aluko Oluwasegun Peter, Department of Religious Studies, Obafemi Awolowo University, Ile-Ife, Nigeria, segmoroc@gmail.com 
Aluko: Tolerance in multi-religious society...

\section{References}

Adamo, David T. "Christianity and the African Traditional Religion(s): The Postcolonial Round of Engagement." Verbum et Ecclesia 32.1 (2011): doi:10.4102/ve.v32i1.285. <http://www.ve.org.za/index.php/VE/article/view/285/808>. Adefarasin, V. O. "An Exposition of Manipulation of Religions in the Society." Religion, Leadership and Society: Focus on Nigeria. Ed. Ade P. Dopamu et al. Lagos: Free Enterprise, 2004.

Babalola, E. O. "The Persistence of African Traditional Medicine in the Contemporary Nigerian Society - The Yoruba Case Study." Africana Marburgensia XXVI.1+2 (1993): 4-13.

Chinmoy, Sri. Earth's Cry Meets Heaven's Smile, Part 2. New York: Agni Press, 1974.

Comparison Chart: Christianity and Islam. n.d. Online. 20th July 2014.

$<$ http://www.religionfacts.com/christianity/charts/christianit y_islam.htm $>$ The inclusion of the African Traditional Religion is a later addition by the Researcher.

Ekeke, Emeka C. and Ekeopara, Chike A. . God, divinities and spirits in African traditional religious ontology. n.d. 22nd July 2014. <http://kwekudeetripdownmemorylane.blogspot.com/2012/09/africans-andtheir-names-for-god.html>.

Fasiku, Gbenga. "Yorùbá Proverbs, Names and National Consciousness." The Journal of Pan African Studies 1.4 (2006): 50-63.

Kalilombe, P. A. "The Salvific Value of African Religions." Mission Trends. Ed. G. H. Stransky \& T.F. Anderson. Grand Rapids, MI: Wm B Eerdmans, 1981. 50-68.

Lateju, F. T. Guidelines for Christian Witnessing Among Muslims. Ibadan: Baptist Press, 2002.

Macmillan Dictionary (online version). n.d. 20th July 2014. $<\mathrm{http}: / /$ macmillandictionary.com $>$.

Mbiti, John S. African Peoples and their Names for God. n.d. Online. 22nd July 2014. $<$ http://www.afrikaworld.net/afrel/afnames.htm>.

- "The Dialogue between African Religion and Christianity (lecture notes)." n.d. Confluence: Ben Byerly's Muddy. 20th 
July 2014.

<http://benbyerly.wordpress.com/2010/05/24/john-mbitithe-dialogue-between-african-religion-and-christianity/>.

- . "The Encounter of Christian Faith and African Religion." Christian Century (1980): 817-820. 21st July 2014. $<\mathrm{http}: / /$ www.religiononline.org/showarticle.asp?title=1746>.

National Security. n.d. 20th July 2014. <http://www.en.wikipedia.org/wiki/National_Security>.

Oborji, F. A. "In Dialogue with African Traditional Religion: New Horizon." Mission Studies 19.1 (2002): 13-34.

Owoeye, S. A. "Harvest of Religious Conflicts in Post-Independent Nigeria, 1980-2002." ALORE: Ilorin Journal of the Humanities Vol. 15 (2005): 194-200.

Oxford Dictionary (online version). n.d. 20th July 2014. $<$ http://www.oxforddictionaries.com>.

Paleri, Pranbhakaran. National Security: Imperatives and Challenges . New Delhi: Tata McGraw-Hill, 2008.

Reese, William L. Dictionary of Philosophy and Religion: Eastern and Western Thought. New Jersey: Humanities Press, 1980.

Robinson, B. A. Religious Tolerance and Cooperation. n.d. 20th July 2014. $<$ http://www.religioustolerance.org_homepage_glossaryofte rms $>$.

The Qur'an and Tolerance of other Religions. n.d. 20th July 2014. $<\mathrm{http}: / / \mathrm{www}$.islamonline.com/news/articles/>.

Webster's New Explorer Encyclopedic Dictionary. Massachusetts: Federal Street Press, 2006. 